\title{
A Study on Work Life Balance of Women Faculties in Arts and Science College with Special Reference to Chennai City
}

\author{
Sugabradhayini $\mathbf{M}^{1}$ \\ ${ }^{1} \mathrm{UG}$ - Department of Commerce Information Systems Management, \\ Shrimathi Devkunvar Nanalal Bhatt Vaishnav College for Women, Chennai, Tamil Nadu.
}

\begin{abstract}
Women are the structure squares of the general public particularly the instructors. It is hard for women to work for the duration of the day by dealing with the plans for getting work done just as the family when children are near. The associations consistently interest in increasingly more execution. The women representatives think that it's difficult to oversee thus called balance between serious and fun activities will be broken. This study has made an endeavour to discover the balance between serious and fun activities among women resources in expressions and science school. The study additionally illuminates the elements which could improve the balance between serious and fun activities.
\end{abstract}

Keywords: Representatives, Structure Squares, Consistently.

\section{INTRODUCTION}

The balance between serious and fun activities can be characterized as the ideal combination between work and life, both not meddling with one another. In the current business world, individuals and associations are working nonstop to satisfy the continuously developing needs. A slight postponement in gathering the timetables or assumptions is viewed as an authoritative disappointment. To stay away from postponements and disappointments, representatives are trying sincerely and giving their substance to balance strenuous and fun activities, causing enormous tension. Thus they are compelled to complete their positions regardless of as far as possible. The regularly utilized expression among the workers is that they do not have time or have a rushed timetable. A day of 24 hours is not, at this point, enough to perform business-related and individual-related obligations or duties. The issue appears to be straightforward yet hard to settle and deal with. Workers who need to assume another part of little girl/child/companion/guardians cannot deal with their jobs. Noticing the everyday existences of numerous representatives, two primary issues to be routed to accomplish a balance between fun and serious activities are time and stress. Dealing with these two factors is the mystery of an ideal balance between serious and fun activities. The HR division of the association should help the worker keep a balance between serious and fun activities. The HR supervisor should cautiously distinguish the issue and discover an answer with the collaboration of the business. The association should incorporate a giving balance between serious and fun activities as an HR strategy.

\section{OBJECTIVES OF THE STUDY}

2.1 To study about work life environment of women faculties of arts and science college in Chennai city

2.2 To analyse the problems faced by the women faculty while balancing personal life and work life

2.3 To know about work life balance policy in an organisation

\section{SCOPE OF THE STUDY}

3.1 The scope of the study is to analyse the work life balance among the college Faculties in Chennai city.

3.2 The study covers to identify the possible, feasible ideas to overcome the imbalance and improve the work life balance of employees.

\section{LIMITATION OF THE STUDY}

4.1 The study is extended to Chennai city only

4.2 The study limited to 100 respondents

4.3 Result of the study has declared based on respondents answer so the result might be uneven 


\section{International Advanced Research Journal in Science, Engineering and Technology}

Vol. 8, Issue 6, June 2021

DOI: $10.17148 /$ IARJSET.2021.8631

4.4 The undertaken research is related to work life balance issues of women faculty employed in arts and science colleges only.

4.5 The study is conducted in selected arts and science colleges only.

\section{REVIEW OF LITERATURE}

5.1 Dr. G. Balamurugan, M. sreeleka (2020) The study analysis the work life balance of women employees in IT sector. The sample size is 60 and analysed using simple percentage analysis, chi-square and correlation. The study has been concluded that women employee in IT sector have good work life balance.

5.2 Dr. J. Jeya Sunita, Dr. R. Mohanaselvi, Dr. P. Prabhakaran (2020) The study analysis the work life balance of college faculties in management studies staff. The sample size is60and analysed using simple percentage analysis, chisquare and correlation. The study has been concluded that faculties in management studies have good work life balance. 5.3 Dhavalai Kaliyanda Bopanna Kushi, Divyasree (2019) The study analysis the work life balance of women teachers in a Mangalore engineering college. The sample size is30and analysed using mean, standard deviations, chi square and Rank. The study has been concluded that it is required to given a more consideration for teachers in order to build good organisation.

5.4 Dr. A. Irin sutha (2019) The study analysis the work life balance of women professors working in selected college. The sample size is50and analysed using percentage analysis and chi square. The study has been concluded that responsibility with greater accountability with greater accountability would help to create a good environment at the work place and also strengthens family bond.

5.5 Dr. Shwetha Sharma, Dr. Sanjeevni Gangwanai (2019) The study analysis the work life balance of working women. The sample size is50and analysed using reliability statics, KMO and Bartlett's test and factor analysis. The study has been concluded that women who is responsible for all the chores of house along with giving best in balancing of both the life. so that will in turn result in balanced life of all the members of family and press who are related with women

\section{RESEARCH METHODOLOGY}

Primary data: The data was collected through well-structured questionaries.

Secondary data: The data was collected through journals, books, websites

Sample size: The researcher fixed sample size as 100

Sample design: The sample design used in this research was convivence sampling technique

Sample area: The researcher has fixed sample area as Chennai city arts and science college.

Tools Used: Percentage analysis, Chi square, Annova, Factor analysis

Statistical package: SPSS 25.0

\section{DATA ANALYSIS}

4.6 Table showing demographic information of the respondents

\begin{tabular}{|l|l|l|}
\hline Age & No of respondents & percentage \\
\hline $25-30$ & 35 & $35 \%$ \\
\hline $30-35$ & 16 & $16 \%$ \\
\hline $35-40$ & 30 & $30 \%$ \\
\hline More than 40 & 19 & $19 \%$ \\
\hline Total & $\mathbf{1 0 0}$ & $\mathbf{1 0 0 \%}$ \\
\hline Marital status & No of respondents & percentage \\
\hline Married & 79 & $79 \%$ \\
\hline Un married & 21 & $21 \%$ \\
\hline Total & $\mathbf{1 0 0}$ & $\mathbf{1 0 0 \%}$ \\
\hline Qualification & No of respondents & Percentage \\
\hline M.Phil. & 59 & $59 \%$ \\
\hline PhD & 41 & $41 \%$ \\
\hline Total & $\mathbf{1 0 0}$ & $\mathbf{1 0 0 \%}$ \\
\hline Designation & No of respondents & percentage \\
\hline Assistant professor & 74 & $74 \%$ \\
\hline Associate professor & 13 & $13 \%$ \\
\hline Head Of the department & 13 & $13 \%$ \\
\hline & &
\end{tabular}


International Advanced Research Journal in Science, Engineering and Technology

Vol. 8, Issue 6, June 2021

DOI: $10.17148 /$ IARJSET.2021.8631

\begin{tabular}{|c|c|c|c|c|}
\hline \multirow{13}{*}{ Source: } & Total & 100 & $100 \%$ & \multirow{13}{*}{ primary data } \\
\hline & Experience in years & No of respondents & percentage & \\
\hline & $0-5$ & 37 & $37 \%$ & \\
\hline & $5-10$ & 18 & $18 \%$ & \\
\hline & $10-15$ & 27 & $27 \%$ & \\
\hline & More than 15 & 18 & $18 \%$ & \\
\hline & Total & 100 & $100 \%$ & \\
\hline & Monthly income & No of respondents & Percentage & \\
\hline & $20,000-30,000$ & 71 & $71 \%$ & \\
\hline & $30,000-40,000$ & 18 & $18 \%$ & \\
\hline & $40,000-50,000$ & 7 & $7 \%$ & \\
\hline & More than 50,000 & 4 & $4 \%$ & \\
\hline & Total & 100 & $100 \%$ & \\
\hline
\end{tabular}

\section{INTERPRETATION}

Above table shows that majority of the respondents are comes under 25-30 years of age group, 79\% of the respondents are married, Majority of the respondents are assistant professors, $37 \%$ of the respondents are having $0-5$ years of experience in teaching field and atmost $71 \%$ of the respondents are earning from $20,000-30,000$ as there monthly income .

4.7 Table showing chi-square analysis of type of organisation and inspiration of work place HO There is no significant difference between type of organization and work place inspiration H1 There is significant difference between type of organization and work place inspiration

\begin{tabular}{|c|c|c|c|}
\hline \multicolumn{4}{|c|}{ Chi-Square Tests } \\
\hline & Value & df & $\begin{array}{l}\text { Significance (2- } \\
\text { sided) }\end{array}$ \\
\hline Pearson Chi-Square & $4.486^{\mathrm{a}}$ & 4 & .344 \\
\hline Likelihood Ratio & 5.255 & 4 & .262 \\
\hline Linear-by-Linear Association & 2.541 & 1 & .111 \\
\hline $\mathrm{N}$ of Valid Cases & 100 & & \\
\hline
\end{tabular}

a. 5 cells $(55.6 \%)$ have expected count less than 5 . The minimum expected count is

Source spss 25.0 .48 .

\section{INTERPRETATION}

The table show that chi-square value is $4.486^{\mathrm{a}}$ with $\mathrm{p}$ value of 0.344 . Since $\mathrm{p}$ value is greater than the 0.05 , we accept null hypothesis the test has concluded that "there is significant difference between type of organization and work place inspiration."

4.8 Table showing one-way annova of travelling hour and tiredness of travelling time HO There is no significant difference between travelling time and tiredness for travel H1 There is significant difference between travelling time and tiredness for travel

\begin{tabular}{lrrrrr|r} 
& Sum of Squares & df & Mean Square & F & \multicolumn{1}{c}{ Sig. } \\
\hline Between Groups & 1.654 & 3 & .551 & 1.031 & .383 \\
\hline Within Groups & 51.346 & 96 & .535 & & \\
\hline Total & 53.000 & 99 & & & \\
\hline
\end{tabular}

Source : spss 25.0

\section{INTERPRETATION}

The $\mathrm{f}$ - statistic score is 1.031 with $\mathrm{p}$ value 0.383 . since $\mathrm{p}$ value is greater then the 0.05 we accept the null hypothesis in simple research can conclude that "There is significant difference between travelling time and tiredness for travel" 
International Advanced Research Journal in Science, Engineering and Technology

Vol. 8, Issue 6, June 2021

DOI: $10.17148 /$ IARJSET.2021.8631

4.9 Table showing factor analysis of peers and superior, organisation, work life and personal life orient

\begin{tabular}{|c|c|c|c|c|c|}
\hline Factor & Components & Item description & Factor loading & \%variance & Elgen value \\
\hline \multirow[t]{6}{*}{ I } & \multirow{6}{*}{$\begin{array}{l}\text { Peers and superior } \\
\text { oriented }\end{array}$} & Taking care well being & 0.875 & \multirow[t]{6}{*}{41.433} & \multirow[t]{6}{*}{41.433} \\
\hline & & Helping tendency & 0.881 & & \\
\hline & & Pride in accomplishment & 0.652 & & \\
\hline & & Failure to notice work & 0.735 & & \\
\hline & & Discrimination & 0.784 & & \\
\hline & & Negative response & 0.856 & & \\
\hline \multirow[t]{6}{*}{ II } & \multirow{6}{*}{$\begin{array}{l}\text { Organisation } \\
\text { oriented }\end{array}$} & Deadline & 0.830 & \multirow[t]{6}{*}{14.255} & \multirow[t]{6}{*}{55.688} \\
\hline & & Slow process in performance & 0.535 & & \\
\hline & & Lack of work autonomy & 0.648 & & \\
\hline & & Promotion policy & 0.839 & & \\
\hline & & Programme by institution & 0.772 & & \\
\hline & & Teaching aids & 0.776 & & \\
\hline \multirow[t]{7}{*}{ III } & \multirow[t]{7}{*}{ Work life oriented } & Managing students & 0.705 & \multirow[t]{7}{*}{7.162} & \multirow[t]{7}{*}{62.850} \\
\hline & & Answer paper valuation & 0.657 & & \\
\hline & & Question paper setting & 0.873 & & \\
\hline & & Work pressure & 0.777 & & \\
\hline & & Work hour & 0.525 & & \\
\hline & & Managing other responsibility & 0.694 & & \\
\hline & & $\begin{array}{l}\text { Participation of students in } \\
\text { activity }\end{array}$ & 0.480 & & \\
\hline \multirow[t]{5}{*}{ IV } & \multirow{5}{*}{$\begin{array}{l}\text { Personal } \\
\text { oriented }\end{array}$} & Attending family function & 0.698 & \multirow[t]{5}{*}{5.235} & \multirow[t]{5}{*}{68.084} \\
\hline & & Parenting issue & 0.714 & & \\
\hline & & Taking care of dependent & 0.693 & & \\
\hline & & Health related issues & 0.832 & & \\
\hline & & Doing college work in home also & 0.804 & & \\
\hline
\end{tabular}

source spss :25.0

\section{INTERPRETATION}

The above table shows that peers and superior oriented factor has showing the variance percentage as 41.433 , Organisation oriented factor has showing the variance percentage as 55.688. Work life-oriented factor has showing the variance percentage as 62.850. Personal life-oriented factor has showing the variance percentage as 68.084.

4.10 Table showing chi square of marital status and worrying about balance work life

HO there is no significant difference between marital status and worrying about balancing work life

H1 there is significant difference between marital status and worrying about balancing work life .

\begin{tabular}{lc|cr} 
& Value & df & \multicolumn{2}{c}{$\begin{array}{c}\text { Asymptotic } \\
\text { Significance (2- } \\
\text { sided) }\end{array}$} \\
\hline Pearson Chi-Square & $13.901^{\mathrm{a}}$ & 3 & .003 \\
\hline Likelihood Ratio & 14.500 & 3 & .002 \\
\hline Linear-by-Linear Association & 10.143 & 1 & .001 \\
\hline N of Valid Cases & 100 & & \\
\hline a. 2 cells $(25.0 \%)$ have expected count less than 5. The minimum expected
\end{tabular}

Source spss: 25.0 count is 2.52 .

\section{INTERPRETATION}

The table show that chi-square value is $13.901^{\mathrm{a}}$ with $\mathrm{p}$ value of 0.003 . Since $\mathrm{p}$ value is less than the 0.05 , we reject null hypothesis the test has concluded that "there is significant difference between marital status and worrying about balancing work life."

4.11 Table showing chi square analysis of designation and missed out quality time with family and friends HO there is no significant difference between designation and missed out quality time with family and friends 
International Advanced Research Journal in Science, Engineering and Technology

Vol. 8, Issue 6, June 2021

DOI: $10.17148 /$ IARJSET.2021.8631

H1 there is significant difference between designation and missed out quality time with family and friends.

Source: spss 25.0

\begin{tabular}{l|rrrr} 
& & & \multicolumn{2}{c}{ Chi-Square Tests } \\
& Value & df & & $\begin{array}{c}\text { Agnificatic } \\
\text { sided) }\end{array}$ \\
\hline Pearson Chi-Square & $7.850^{\mathrm{a}}$ & 4 & .097 \\
\hline Likelihood Ratio & 10.729 & 4 & .030 \\
\hline Linear-by-Linear Association & 7.486 & 1 & .006 \\
\hline N of Valid Cases & 100 & & \\
\hline
\end{tabular}

a. 4 cells (44.4\%) have expected count less than 5 . The minimum expected count is 1.82 .

\section{INTERPRETATION}

The table show that chi-square value is $4.486^{\mathrm{a}}$ with $\mathrm{p}$ value of 0.097 . Since $\mathrm{p}$ value is greater than the 0.05 , we accept null hypothesis the test has concluded that "there is significant difference between designation and missed out quality time with family and friends ."

4.12 Table showing chi-square of Age and hindrance in adjusting work life with personal life $\mathrm{HO}$ there is no significant difference between Age and hindrance in adjusting work life with personal life. H1 there is significant difference between Age and hindrance in adjusting work life with personal life.

Source:spss25.01

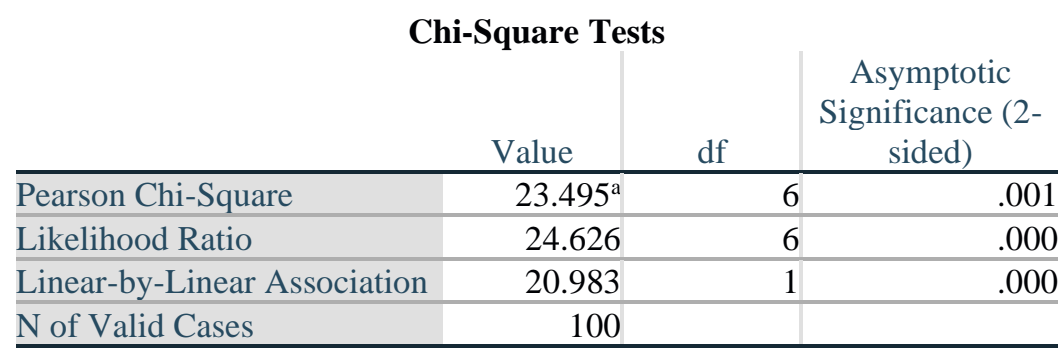

a. 3 cells $(25.0 \%)$ have expected count less than 5 . The minimum expected count is 3.04 .

\section{INTERPRETATION}

The table show that chi-square value is $23.495^{\mathrm{a}}$ with $\mathrm{p}$ value of 0.001 . Since $\mathrm{p}$ value is less than the 0.05 , we reject null hypothesis the test has concluded that "there is significant difference between Age and hindrance in adjusting work life with personal life."

4.13 Table showing two-way annova of work life balance policy health related programme and chreche facility $\mathrm{HO}$ there is no significant difference between availability of work life balance policy and health related programme $\mathrm{H1}$ there is significant difference between availability of work life balance policy and health related programme HO there is no significant difference between availability of work life balance policy and chreche facility HO there is significant difference between availability of work life balance policy and chreche facility

Tests of Between-Subjects Effects

Dependent Variable: Does your organisation provide you casual leave?

\begin{tabular}{lr|r|r|r|r} 
Source & $\begin{array}{c}\text { Type III Sum of } \\
\text { Squares }\end{array}$ & df & Mean Square & F & \multicolumn{1}{c}{ Sig. } \\
\hline Corrected Model & $.173^{\mathrm{a}}$ & 4 & .043 & .896 & .469 \\
\hline Intercept & 50.137 & 1 & 50.137 & 1040.584 & .000 \\
\hline Health programme & .151 & 2 & .076 & 1.568 & .214 \\
\hline chreche facility & .015 & 2 & .008 & .160 & .852 \\
\hline Error & 4.577 & 95 & .048 & & \\
\hline
\end{tabular}


DOI: $10.17148 /$ IARJSET.2021.8631

\begin{tabular}{lrr|l}
\hline Total & 115.000 & 100 & \\
\hline Corrected Total & 4.750 & 99 & \\
\hline a. R Squared $=.036$ (Adjusted R Squared $=$ & $-.004)$
\end{tabular}

\section{INTERPRETATION}

The factor of Health programme has a F-statistic of 1.568 with p value 0.214 . Since the p-value is greater than 0.05 we accept null hypothesis i.e., "there is no significant difference between availability of work life balance policy and health related programme"

The factor of chreche facility has a F-statistic of 0.160 with p value 0.852 . Since the $\mathrm{p}$ - value is greater than 0.05 we accept null hypothesis i.e., "there is no significant difference between availability of work life balance policy and chreche facility"

\section{FINDINGS}

4.14 The study shows that the influence of organization is essential in a work-life environment

4.15 Most of the respondents are tired because of their travelling time

4.16 The study draws a line between peers and superior oriented factor, organization factor, work-life factor and personal-life factor in that personal-life factor has influenced more than others

4.17 The study says that married respondents are worried more about balancing work life with personal life

4.18 The study reveals that assistant professors are missed out on quality time with their family and friends

4.19 The study explains that most of the young respondents are not able to balance work life with personal life

4.20 The study says that most of the respondents are aware of work-life balance policies provide by the organization

4.21 The study reveals that most of the respondents not aware of the work-life programme organized by the institution

\section{SUGGESTIONS}

4.22Reducing workload would likely be the most effective way to reduce stress.

4.23Make course clustering and partial leave uniformly available and increase faculty awareness of policies and programs.

4.24Work-life balance policies like a flexible working hour, flexible leave, the possibility of teleworking, emergency child care.

4.25The organisation should tell the faculties about the availability of a work-life balance programme

4.26In order to achieve work-life balance, time management, involvement in work, and satisfaction should be considered.

4.27The organisation should not tell the faculties to work more than the work hour

4.28The organisation should conduct workshop, webinar, FDP to reduce stress during the work hour

4.29The organisation should take care of the wellbeing of the professors, so that have to take health care of the professors

\section{CONCLUSION}

Balance between fun and serious activities is an issue vital that must be tended to by the Associations at the most punctual. After every one of the representatives is the best resource, the association's exhibition is influenced by worker execution. The association and the representatives should work out methodologies to help achieve Work-life balance, making the association the most joyful work environment. Regardless of more significant compensations and other money related and non-financial advantages, an open to working space, less responsibility, and associations dealing with representatives, it is seen that occasionally workers neglect to convey anticipated deals. Even though various variables influence the exhibition of a representative, accomplishing balance in work and day-to-day life is viewed as significant to perform second to none. The harmony among expert and individual life improves execution at work and helps in acquiring position fulfilment. It gives a sensation of happiness and spurs the person to bear duties with more major responsibility. It helps establish a pleasant climate in the working environment and fortifies the family obligations of the representatives.

\section{REFERENCES}

1. Dr. Balamurugan, sreeleka.M (2020) "A STUDY ON WORK LIFE BALANCE OF WOMEN EMPLOYEES IN IT SECTOR", international journal of engineering technologies and management research, ISSN: 2454-1907, volume-7, issue-1

2. Dhavalai Kaliyanda Bopanna Kushi, Divyasree (2019) “A STUDY ON WORK LIFE BALANCE OF WOMEN TEACHERS IN A MANGLORE ENGENEERING COLLEGE”, Asian journal of education and social studies, ISSN: 2581-6268.

3. Dr. Irin sutha. A (2019) "A STUDY ON WORK LIFE BALANCE OF WOMEN PROFESSORS WORKING IN SELECTED COLLEGE IN CHENNAI CITY”, International journal of management, ISSN: 0976-6502, Volume-10, Issue-4. 


\section{IARJSET}

\section{International Advanced Research Journal in Science, Engineering and Technology}

Vol. 8, Issue 6, June 2021

DOI: $10.17148 / I A R J S E T .2021 .8631$

4. Dr. Jeya Sunita. J, Dr. Mohanaselvi. R, Dr. Prabhakaran. P (2020) “A STUDY ON WORK LIFE BALANCE OF COLLEGE FACULITIES IN DINDUKAL DISTRICT WITH SPECIAL REFERENCE TO MANAGEMENT STUDIES STAFF”, Aegaeum Journal, ISSN No: 0776-3808.

5. Dr. Shwetha Sharma, Dr. Sanjeevni Gangwanai (2019) "A STUDY ON WORK LIFE BALANCE OF WORKING WOMEN PROFESSIONAL: SCALE DEVELOPMENT”, International journal of scientific and technology research, ISSN:2277-8610, Volume-8, Issue-11

\section{REFERENCE BOOKS:}

1. J. Jayashankar, "HUMAN RESOURCE MANAGEMENT", Margham Publications.

2. S.P. Gupta, M.P. Guptha." BUSINESS STATISTICS”. Sultan Chand publications.

3. DR. C.D. Balaji "HUMAN RESOURCE MANAGEMENT", Margham Publications.

WEBSITES

1. www.google.com

2. www.scribd.com

3. www.iiste.org

4. www.iosrjournals.org 